\title{
Novel Pyrazole Based Ionic Liquid as a Corrosion Inhibitor for Mild Steel in Acidic Media
}

\author{
M. R. EZHILARASI, B. PRABHA and T. SANTHI ${ }^{*}$ \\ Department of Chemistry, Karpagam University, Coimbatore-21, Tamilnadu, India \\ ssnilasri@yahoo.co.in
}

Received 22 April 2015 / Accepted 18 May 2015

\begin{abstract}
The corrosive inhibitive effect of compound on mild steel in molar solution of $\mathrm{H}_{2} \mathrm{SO}_{4}$ and $\mathrm{HCl}$ was investigated by weight loss, potentiodynamic polarization and electro chemical impedance studies. 1-Acetyl-4, 5-dihydro-5-phenyl-3-(thiophen-2yl) pyrazoles was synthesized, characterized and structure elucidated by FTIR, ${ }^{1} \mathrm{H}$ NMR, ${ }^{13} \mathrm{C}$ NMR. The corrosion inhibition rate was increased by increasing the concentration of inhibitor (1-acetyl-4, 5-dihydro-5-phenyl-3-(thiophen-2yl) pyrazoles) and decreases with increase in temperature. The interaction between inhibitor and surface of steel obey Langmuir isotherm.
\end{abstract}

Keywords: Pyrazole, Mild steel, Inhibition efficiency, Synergetic effect, Adsorption isotherm, Kinetics

\section{Introduction}

One of the most economical and practical preventive maintenance methods for minimizing and controlling corrosion in product pipelines, vessels, etc., is to treat the corrosive environment with chemical inhibitors ${ }^{1-3}$. It is well documented that, the development of new corrosion inhibitors of nontoxic type, which do not contain heavy metals and organic phosphates was very important ${ }^{4}$. Inorganic compounds such as chromate, dichromate, nitrite and nitrate are widely used as corrosion inhibitors in several media and for different metals and alloys ${ }^{5,6}$. The bio-toxicity of these products, especially chromate, is well documented ${ }^{7}$ because of their non-environmental friendly characteristics ${ }^{8}$ which limit their application. Among alternative corrosion inhibitors, organic compounds containing hetero atom like $\mathrm{N}, \mathrm{S}$ and $\mathrm{O}$ have been reported as inhibitors which reduce the rate of the dissolution of metals in acidic medium ${ }^{9,10}$.

$\mathrm{N}$-Heterocyclic compounds act by adsorption on the metal surface, and the adsorption takes place through nitrogen atom, as well as with triple or conjugated double bonds or aromatic rings in their molecular structures. Up to now, many $N$-heterocyclic compounds, such as imidazoline, triazole, pyrimidine, pyrrole, pyridine, etc., derivatives ${ }^{11-14}$, has been used for the corrosion inhibition of iron or steel in acidic media. In recent years, ionic liquids (ILs) started to receive some interest as new eco-friendly corrosion inhibitors, but still very 
little work have been reported so far ${ }^{15-20}$. On the other hand, there are several reports showing that the inhibition efficiency of heteroatom-containing compounds increase in the order $\mathrm{O}<\mathrm{N}<\mathrm{S}<\mathrm{P}^{21-23}$.

The aim of our present work is to synthesize ionic liquid (1-acetyl-4, 5-dihydro-5phenyl-3-(thiophen-2yl) pyrazoles) derivatives and to evaluate their anticorrosion potential on mild steel in acid media in various temperature.

\section{Experimental}

Mild steel strip has following composition: C-3.15, Mn-0.61, P-0.07, S-0.049, Cu-0.5, Cr$0.155, \mathrm{Sn}-0.035$ and reminder iron were used for weight loss method.

\section{Synthesis of ionic liquid}

Chalcone $(0.01 \mathrm{~mol})$, hydrazine hydrate $(0.01 \mathrm{~mol})$, anhydrous sodium acetate $(0.01)$ and acetic anhydride were taken in a round bottom flask and the reaction mixture flask was refluxed until the products are formed. The completion of reaction was monitored by TLC. The reaction mixture was poured in to crushed ice and left overnight. The precipitate was separated by filtration. Washed, dried and purified by using column chromatography ${ }^{24}$.
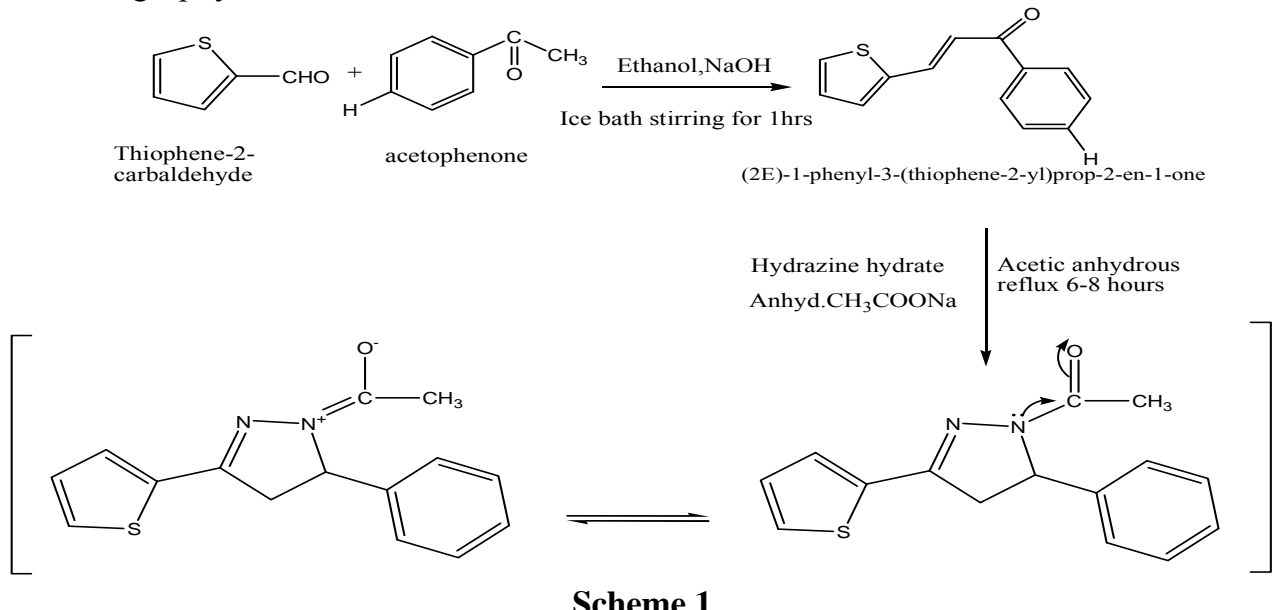

\section{Scheme 1}

Materials and measurement equipments

The materials and measurement equipments are adopted by the literature method ${ }^{24}$.

\section{Corrosion monitoring methods}

\section{Weight loss tests}

Weight loss measurements were performed at different concentration $(10,20,30$ and $40 \mathrm{~mL})$ of inhibitor for $1 \mathrm{~h}$ by placing the carbon steel coupons into the acid solution $(20 \mathrm{~mL})$. At the end of the testing period, the specimens were cleaned and finally its weight loss was recorded. The corrosion rate $\left(V_{\text {corr }}\right)$, inhibition efficiency $\left(\eta \mathrm{E}_{\mathrm{w}} \%\right)^{25}$ and surface coverage $(\theta)$ were determined by the following equations.

$$
v_{\text {corr }}=\frac{8.76 \times 10^{4} \mathrm{w}}{A T D}
$$




$$
\varnothing=\frac{\mathrm{v}_{\text {corr }} \cdot \mathrm{o}-\mathrm{v}_{\text {corr }} \cdot \mathrm{i}}{\mathrm{v}_{\text {cor } \mathrm{r}} \cdot \mathrm{o}}
$$

Where $\mathrm{W}$ is the weight $\operatorname{loss}(\mathrm{g}), \mathrm{D}$ is the steel density $\left(\mathrm{g} \mathrm{cm}^{-3}\right), \mathrm{A}$ is the surface area $\left(\mathrm{cm}^{2}\right), \mathrm{T}$ is the exposure time $(\mathrm{h})$ and $\mathrm{V}_{\text {corr, }, 0}$ and $\mathrm{V}_{\text {corr, }}$ are the weight loss values in the absence and presence of inhibitors, respectively.

$$
\eta w, \%=\left[1-\frac{w_{\text {corr }}}{w_{\text {corr }}^{o}}\right] \times 100
$$

Where $\mathrm{W}_{\text {corr }}$ and $\mathrm{W}_{\text {corr }}^{\mathrm{o}}$ are the weight losses in the presence and absence of inhibitor respectively.

\section{Electrochemical tests}

Electrochemical measurements were performed in a conventional three-electrode glass cell. Electrode potentials were measured against a saturated calomel electrode (SCE), the counter electrode was a mesh of $\mathrm{Pt}$ (purity 99.9\%) and the working electrode was made of mild steel $\left(0.339 \mathrm{~cm}^{2}\right)$. The SCE was connected to a Luggin capillary, the tip of which was placed very close to the surface of the working electrode to minimize IR drop. Tests were performed at $26 \pm 1{ }^{\circ} \mathrm{C}$ and thermostatically controlled. Electrochemical testing was performed in a potentio stat Instrument Model: CHI604D controlled by a PC through the general purpose electrochemical system (GPES); the software provided by AUTOLAB. Corrosion current densities $\left(\mathrm{i}_{\text {corr }}\right)$ obtained by Tafel extrapolations were used to determine the inhibition efficiencies using the equation:

$$
\left(I E_{T} \%\right)=\frac{i^{o}{ }_{\text {corr }}-i^{i}{ }_{\text {corr }}}{i^{o}{ }_{\text {corr }}} \times 100
$$

Where $\mathrm{i}_{\text {corr }}^{\mathrm{i}}$ and $\mathrm{i}_{\text {corr }}^{\mathrm{o}}$ are the corrosion current densities values with and without inhibitor respectively.

\section{Synergistic effect}

The synergistic effect was studied in the presence of decinormal solution of $\mathrm{KCl}$ and $\mathrm{KI}$ to the steel specimen immersed for hours in molar solution of $\mathrm{H}_{2} \mathrm{SO}_{4}$ and $\mathrm{HCl}$ containing various concentration of the inhibitor. The weight loss method procedure was followed to study the synergistic effect.

\section{Results and Discussion}

\section{Structural elucidation of synthesized organic inhibitor}

\section{Analysis of FT-IR spectrum of Inhibitor}

FT-IR spectrum of inhibitor compound shows characteristic absorption frequencies at $3082.25,3022.45 \mathrm{~cm}^{-1}$ due to aromatic $\mathrm{CH}$ stretching vibration. The absorption bands at $2910.58 \mathrm{~cm}^{-1}$ is attributed to the aliphatic $\mathrm{CH}$ stretching vibration. The absorption frequency at $1647.21 \mathrm{~cm}^{-1}$ is assigned to amide carbonyl stretching vibration. The absorption band at $1423.47 \mathrm{~cm}^{-1}$ is assigned to $\mathrm{C}=\mathrm{N}$ stretching vibration. $626.87,702.09,736.81,763.81 \mathrm{~cm}^{-1}$ (Aromatic ring stretching). The absence of carbonyl band clearly supported for the formation of bromo pyrazole, besides the disappearance of $\mathrm{NH}$ stretching vibration, which conforms the situ acetylation reaction due to acetic anhydride solvent. 


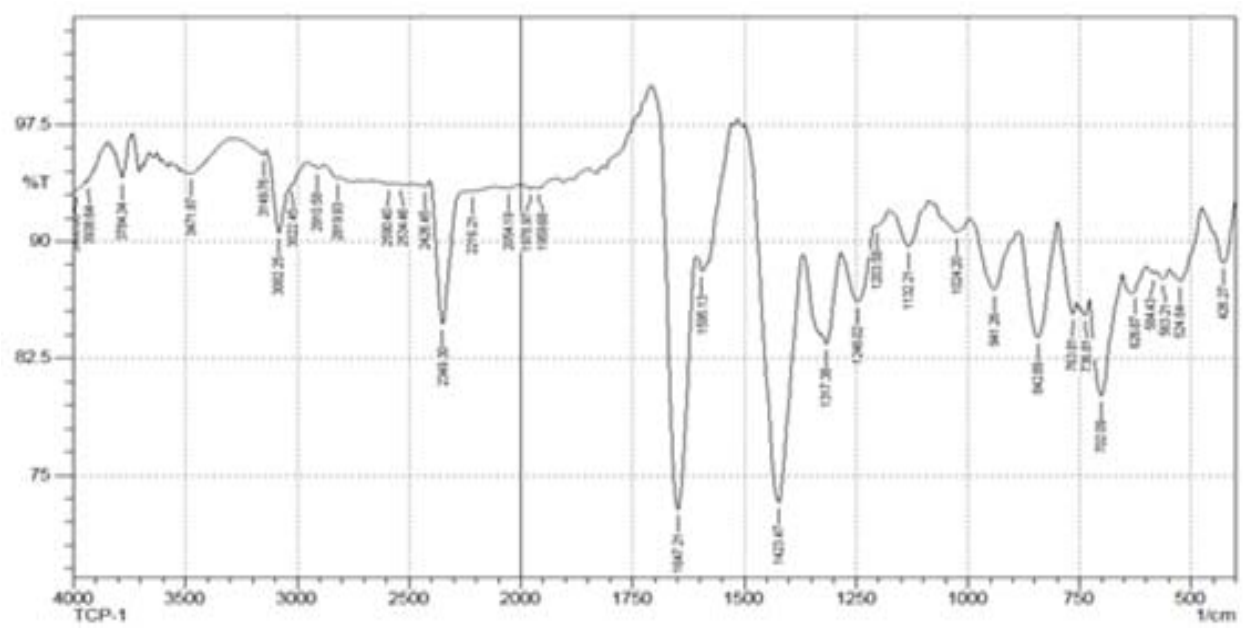

Figure 1. The IR result for the Ionic liquid inhibitor

\section{Analysis of ${ }^{1} H$ NMR spectrum of Inhibitor}

In the ${ }^{1} \mathrm{H}$ NMR spectrum of compound, the methylene protons $(\mathrm{H}-4 \mathrm{a}$ and $\mathrm{H}-4 \mathrm{e})$ of the pyrazoline moiety appeared as two doublets of doublets due to multiple coupling involving both geminal and vicinal protons. The signals for $\mathrm{H}-4 \mathrm{a}$ and $\mathrm{H}-4 \mathrm{e}$ are observed at 3.37 and $3.75 \mathrm{ppm}$. The doublet of doublet at $5.93 \mathrm{ppm}(\mathrm{J} 4 \mathrm{a}, 5 \mathrm{a}=17.5 \mathrm{~Hz}$ and $\mathrm{J} 4 \mathrm{a}, 4 \mathrm{e}=4.0 \mathrm{~Hz})$ is assigned to $\mathrm{H}-4 \mathrm{a}$ proton of the pyrazoline moiety. Likewise, the doublet of doublet at 3.75 ppm $(\mathrm{J} 4 \mathrm{e}, 4 \mathrm{a}=17.5$ and $\mathrm{J} 4 \mathrm{e}, 5 \mathrm{a}=11.5 \mathrm{~Hz})$ is assigned to $\mathrm{H}-4 \mathrm{e}$ proton of the pyrazoline moiety. Similarly, the methine proton (H-5) of the pyrazole moiety is expected to give signal as a doublet of doublet due to vicinal coupling with the two magnetically nonequivalent protons of the methylene group $(\mathrm{H}-4 \mathrm{a}-\mathrm{H} 4 \mathrm{e})$ of the pyrazoline moiety and the signals are observed at $5.93 \mathrm{ppm}(\mathrm{J} 5 \mathrm{a}, 4 \mathrm{a}=11.5 \mathrm{Hzand} \mathrm{J} 5 \mathrm{a}, 4 \mathrm{e}=4.0 \mathrm{~Hz})$. Also the acetyl methyl protons of pyrazoline moiety gives signal as a singlet at $2.43 \mathrm{ppm}$. The aromatic protons appear as a multiplet in the range of 6.93-7.79 ppm.

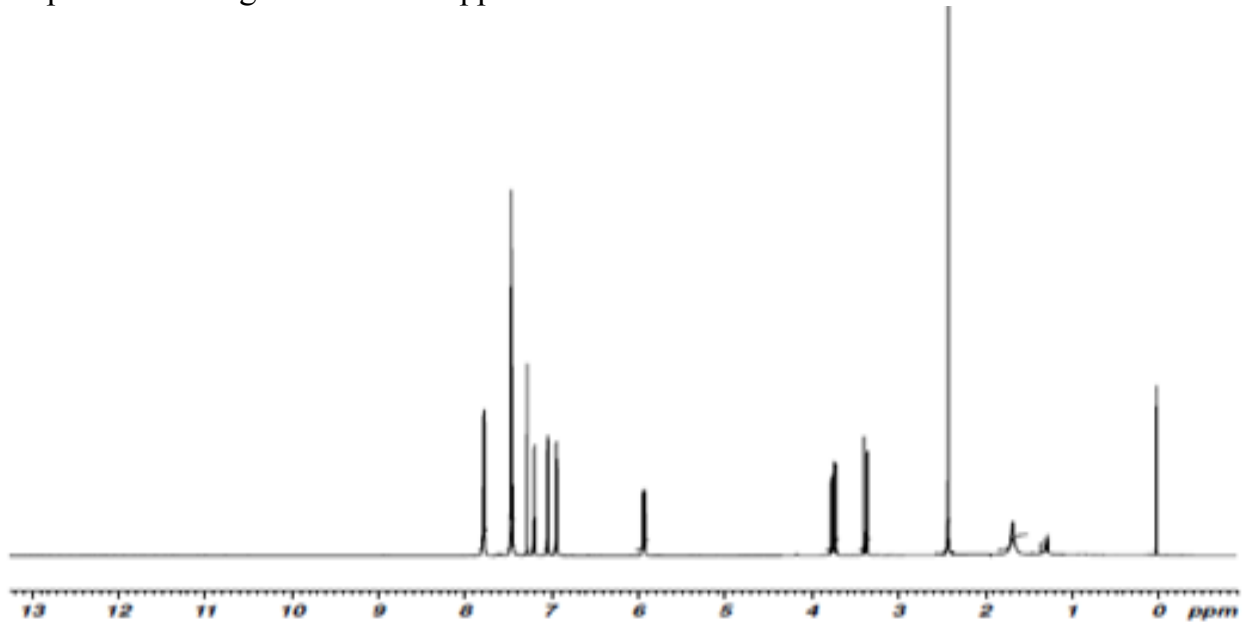

Figure 2. The ${ }^{1} \mathrm{H}$ NMR result for synthesized Ionic liquid inhibitor 


\section{Analysis of ${ }^{13} \mathrm{C}$ NMR spectrum of Inhibitor}

In the ${ }^{13} \mathrm{C}$ NMR spectrum of inhibitor compound, ${ }^{13} \mathrm{C}$ resonance at $55.26 \mathrm{ppm}$ is assigned to $\mathrm{C}-5$ of pyrazole moiety. The ${ }^{13} \mathrm{C}$ resonance observed at $42.04 \mathrm{ppm}$ is due to $\mathrm{C}-4$ of pyrazole moiety. The ${ }^{13} \mathrm{C}$ resonance observed at $153.87 \mathrm{ppm}$ is assigned to $\mathrm{C}-3$ of pyrazole moiety. The aromatic carbons are observed in the region of $124.59-128.59 \mathrm{ppm}$. The ${ }^{13} \mathrm{C}$ resonance observed at $21.98 \mathrm{ppm}$ is due to acetyl methyl carbon. The remaining ${ }^{13} \mathrm{C}$ signal at 144.32 is due to ipso carbon.

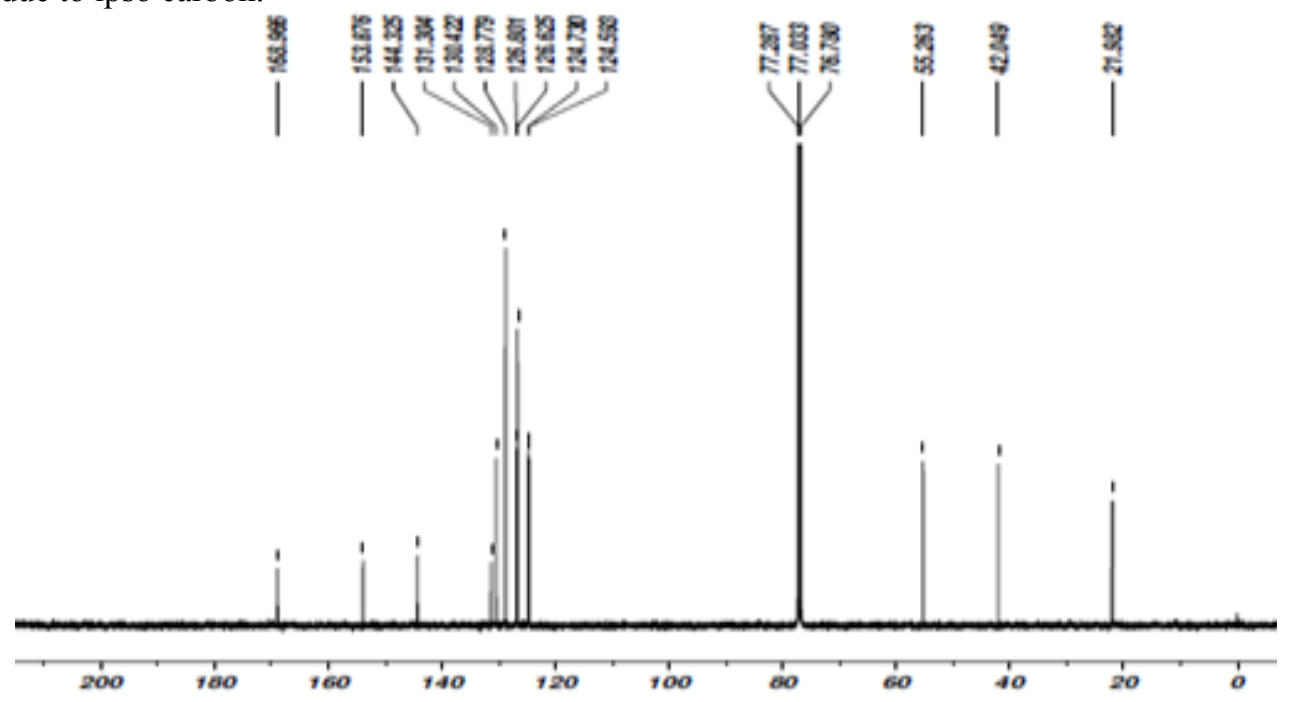

Figure 3. The ${ }^{13} \mathrm{C}$ NMR result for synthesized Ionic liquid inhibitor

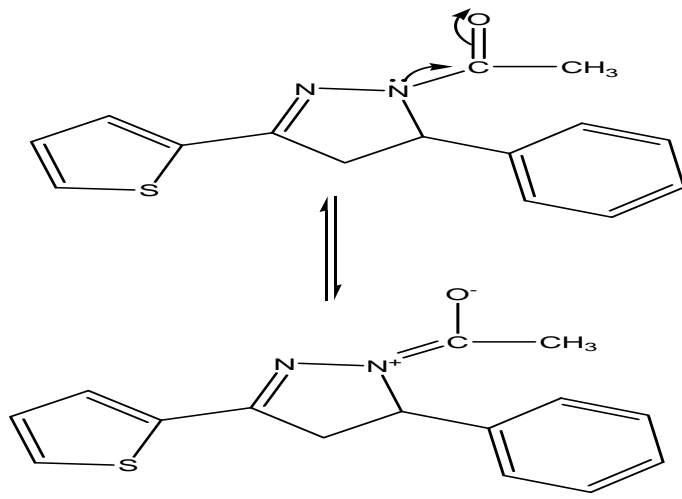

Figure 4. Structure of ionic liquid based inhibitor

\section{Weight loss measurements}

\section{Effect of inhibitor concentration}

The inhibition efficiency with different concentration of the inhibitor on the mild steel in one molarity solution of $\mathrm{H}_{2} \mathrm{SO}_{4}$ and $\mathrm{HCl}$ has been evaluated by weight loss measurements and the results are summarized in Table 1 . The data revels that inhibition efficiency increases with increase in concentration of the inhibitor behavior may be attributed to an increase in surface coverage $(\theta)$ by the adsorption of inhibitor on the mild steel surface, in the aggressvie 
solution, which restricts the dissolution of the metal. The addition of iodide ions enhances the inhibition efficiency to a considerable extent. This is due to the synergistic effect of pyrazoles is adsorbed by columbic interaction on the metal surface, where iodide ions are already adsorbed and thus reduces the corrosion rate.

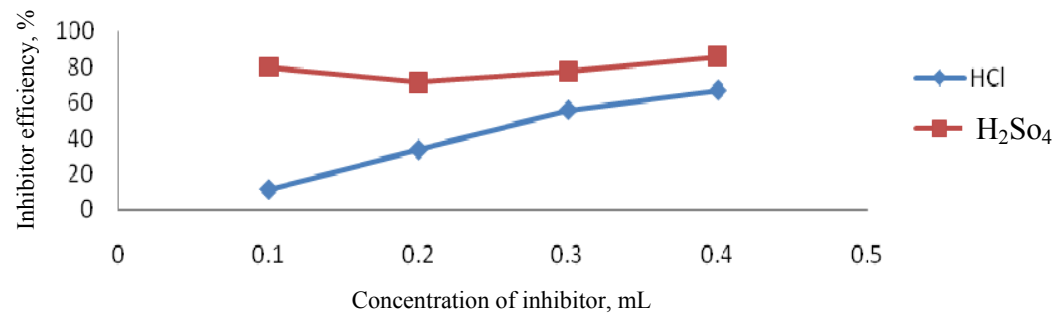

Figure 5. A plot of corrosion efficiency of inhibitor with different concentrations

Table 1. Inhibition efficiency at various concentrations of pyrazole with and without KI for the corrosion of mild steel in one molar solution of $\mathrm{H}_{2} \mathrm{SO}_{4}$ and $\mathrm{HCl}$ obtained by weight loss measurements at $28^{\circ} \mathrm{C}$

\begin{tabular}{|c|c|c|c|c|c|c|}
\hline Medium & $\begin{array}{c}\text { Inhibitor } \\
\text { concentration in \% }\end{array}$ & $\begin{array}{l}\text { Weight } \\
\text { loss in } \\
\mathrm{mg}\end{array}$ & $\begin{array}{c}\text { Inhibition } \\
\text { efficiency } \\
\text { in } \%\end{array}$ & $\begin{array}{l}\text { Degree of } \\
\text { coverage } \\
\text { in } \theta\end{array}$ & $\mathrm{C} / \theta$ & $\begin{array}{l}\text { Corrosion } \\
\text { rate in } \\
\text { mpy } \times 10^{-3}\end{array}$ \\
\hline \multirow[t]{5}{*}{$\mathrm{HCl}$} & blank $(10 \mathrm{~mL}) \mathrm{HCl}$ & 0.009 & - & - & - & 0.0115 \\
\hline & $\mathrm{HCl}+0.1 \mathrm{~S}$ & 0.008 & 11.11 & 0.11 & 90.9091 & 0.01028 \\
\hline & $\mathrm{HCl}+0.2 \mathrm{~S}$ & 0.006 & 33.33 & 0.33 & 60.6061 & 0.0077 \\
\hline & $\mathrm{HCl}+0.3 \mathrm{~S}$ & 0.004 & 55.55 & 0.55 & 54.545 & 0.005158 \\
\hline & $\mathrm{HCl}+0.4 \mathrm{~S}$ & 0.003 & 66.67 & 0.67 & 59.7015 & 0.003869 \\
\hline \multirow[t]{5}{*}{$\mathrm{H}_{2} \mathrm{SO}_{4}$} & blank $(10 \mathrm{~mL}) \mathrm{H}_{2} \mathrm{SO}_{4}$ & 0.035 & - & - & - & 0.0449 \\
\hline & $\mathrm{H}_{2} \mathrm{SO}_{4}+0.1 \mathrm{~S}$ & 0.007 & 80 & 0.80 & 37.5 & 0.00899 \\
\hline & $\mathrm{H}_{2} \mathrm{SO}_{4}+0.2 \mathrm{~S}$ & 0.012 & 71.4 & 0.71 & 28.169 & 0.0128 \\
\hline & $\mathrm{H}_{2} \mathrm{SO}_{4}+0.3 \mathrm{~S}$ & 0.008 & 77.1428 & 0.77 & 38.961 & 0.01028 \\
\hline & $\mathrm{H}_{2} \mathrm{SO}_{4}+0.4 \mathrm{~S}$ & 0.005 & 85.71 & 0.86 & 46.51 & 0.00643 \\
\hline $\mathrm{HCl}+$ & $\mathrm{HCl}+\mathrm{S}+0.1 \mathrm{KI}$ & 0.005 & 44.44 & 0.44 & 22.95 & 0.0064 \\
\hline \multirow[t]{3}{*}{ Halide } & $\mathrm{HCl}+\mathrm{S}+0.2 \mathrm{KI}$ & 0.0024 & 73.33 & 0.73 & 27.39 & 0.0031 \\
\hline & $\mathrm{HCl}+\mathrm{S}+0.3 \mathrm{KI}$ & 0.0029 & 67.77 & 0.68 & 44.12 & 0.0037 \\
\hline & $\mathrm{HCl}+\mathrm{S}+0.4 \mathrm{KI}$ & 0.0032 & 64.44 & 0.64 & 62.5 & 0.0041 \\
\hline \multirow{2}{*}{$\begin{array}{l}\mathrm{H}_{2} \mathrm{SO}_{4} \\
+\end{array}$} & $\mathrm{H}_{2} \mathrm{SO}_{4}+\mathrm{S}+0.1 \mathrm{KI}$ & 0.003 & 91.4 & 0.91 & 11.098 & 0.0038 \\
\hline & $\mathrm{H}_{2} \mathrm{SO}_{4}+\mathrm{S}+0.2 \mathrm{KI}$ & 0.0089 & 74.57 & 0.75 & 26.66 & 0.01105 \\
\hline \multirow[t]{2}{*}{ Halide } & $\mathrm{H}_{2} \mathrm{SO}_{4}+\mathrm{S}+0.3 \mathrm{KI}$ & 0.0056 & 84 & 0.84 & 35.7 & 0.0072 \\
\hline & $\mathrm{H}_{2} \mathrm{SO}_{4}+\mathrm{S}+0.4 \mathrm{KI}$ & 0.0044 & 88 & 0.88 & 45.45 & 0.0054 \\
\hline
\end{tabular}

\section{Effect of temperature and kinetic-thermodynamic}

The effect of temperature on the inhibitive performance of inhibitor for steel in one molar solution of $\mathrm{H}_{2} \mathrm{SO}_{4}$ and $\mathrm{HCl}$ was studied by electrochemical measurements. It is apparent from Figure 6. That shows the inhibition efficiency decreases with increase in temperature. This can be explained in terms of physical adsorption of inhibitor molecule on steel surface. The values of Ea were calculated using Arrhenius equation ${ }^{26}$.

$$
\log \left(i_{\text {corr }}\right)=-\frac{E a}{2.303 R T}+\log A
$$


The values of standard enthalpy of activation $\left(\Delta \mathrm{H}_{\mathrm{a}}^{\circ}\right)$ and standard entropy of activation $\left(\Delta \mathrm{S}_{\mathrm{a}}^{\circ}\right)$ for the dissolution of steel were calculated using the following equation ${ }^{25}$.

$$
i_{\text {corr }}=\frac{R T}{N h} \exp \left\{\frac{\Delta S^{o}}{R}\right\} \exp \left\{-\frac{\Delta H^{o}}{R T}\right\}
$$

Where, the terms have usual meaning. The values of Ea and $\Delta \mathrm{H}^{\circ}{ }_{\mathrm{a}}$ should ideally be equal for a chemical reaction in electrolytic solutions. The values of these parameters are not shown that there is almost a constant. The values of $\Delta \mathrm{S}_{\mathrm{a}}^{\circ}$ both in the absence and in the presence of inhibitor are negative. This indicates that the effect of the inhibitor. A decrease in inhibition efficiency with rise in temperature, suggests a possible desorption of some adsorbed inhibitor molecules from the metal surface at higher temperatures.

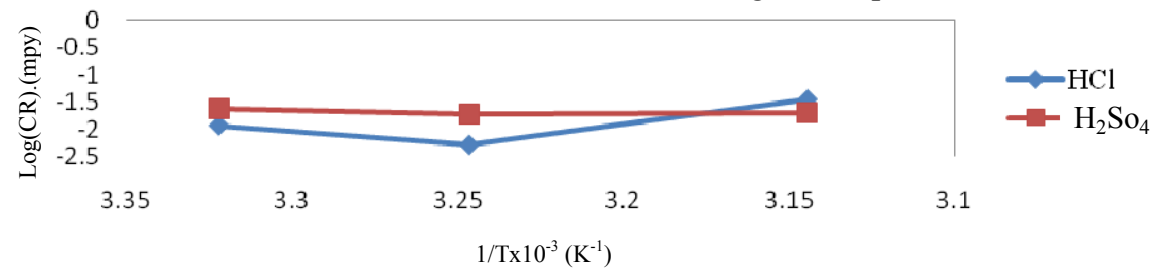

Figure 6. Arrhenius plot of corrosion rate of mild steel in one molar solution of $\mathrm{H}_{2} \mathrm{SO}_{4}$ and $\mathrm{HCl}$ in presence and absence of the inhibitors.

Table 2. Effect of temperature on inhibition efficiency of pyrazole at $0.01 \mathrm{~mL}$ concentration in one molar solution of $\mathrm{H}_{2} \mathrm{SO}_{4}$ and $\mathrm{HCl} \mathrm{S}$ - Inhibitor

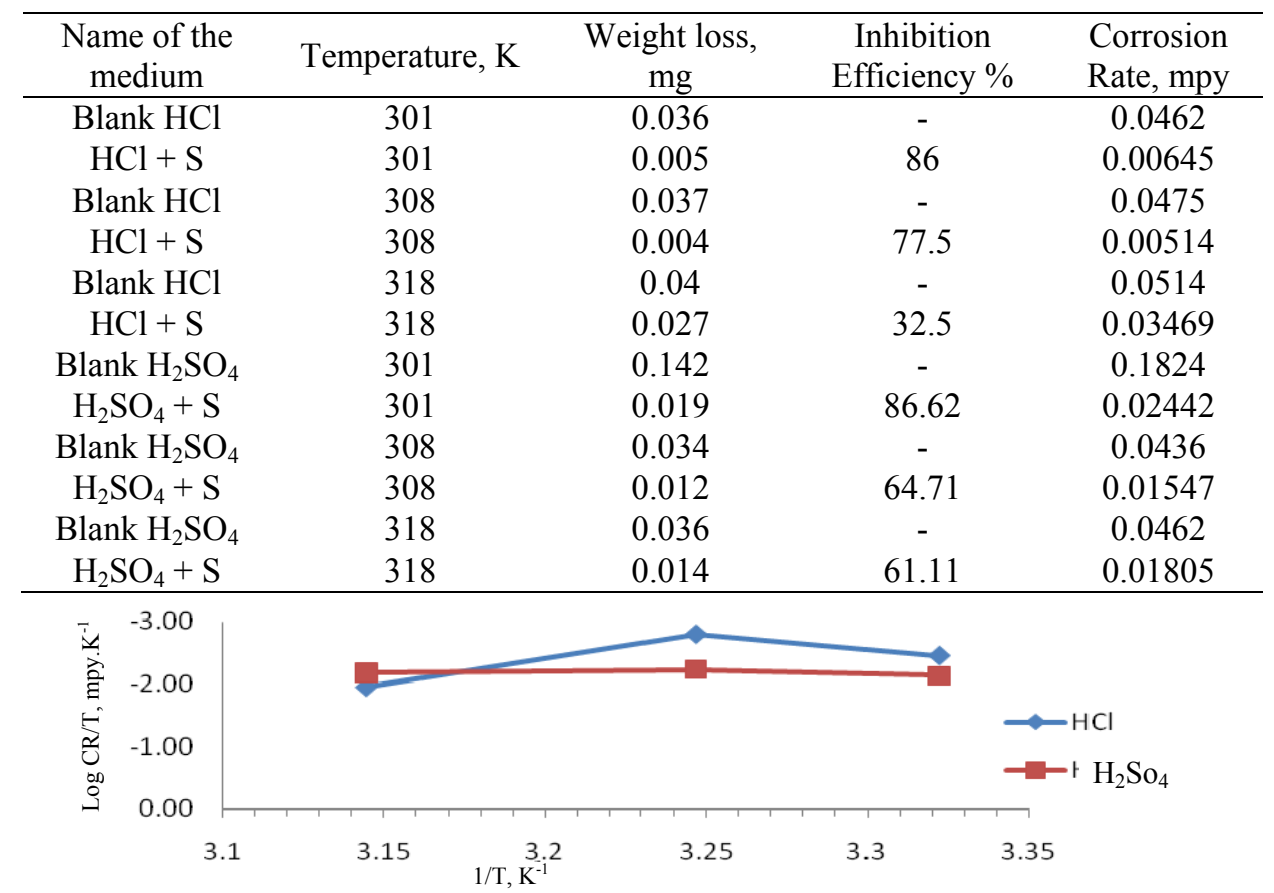

Figure 7. $\log$ (corrosion rate/T) - $(1 / \mathrm{T})$ curves for dissolution in one molar solution of $\mathrm{HCl}$ and $\mathrm{H}_{2} \mathrm{SO}_{4}$ in absence and presence of inhibitor 


\section{Adsorption isotherm}

The interaction of inhibitor and steel surface was described on the model followed by adsorption isotherms. The degree of surface covered $(\theta)$ by inhibitor on steel is dependent on inhibitor concentration at constant temperature. Classical model of adsorption were applied to fit the surface coverage values at different inhibitor concentrations and temperatures. Experimental results of $(\mathrm{C} / \theta)$ vs. C yielded straight lines as shown in Figure 8, which are in agreement with Langmuir's isotherm:

$$
K_{a d s} C=\frac{\theta}{1-\theta}
$$

Where $\mathrm{C}$ is the inhibitor concentration and $\mathrm{K}_{\mathrm{ads}}$ is the adsorption equilibrium constant. Correlation coefficients and slope profile indicated a good fitting of experimental data to Langmuir's isotherm. When the degree of surface coverage $(\theta)$ tends to 1 , a more compact film is formed though this is dependent on the molecular structure of compounds ${ }^{25}$ :

$$
\Delta G=-R T \operatorname{In}\left(55 K_{a d s}\right)
$$

An increase in $\mathrm{K}_{\mathrm{ads}}$ with temperature indicates an increase in the extent of adsorption and consequently emphasized anticorrosion activity of inhibitor. The increased negative values of $\Delta \mathrm{G}_{\text {ads }}^{0}$ values are determined a higher spontaneity of adsorption along with an increase in the stability of the adsorbed layer.

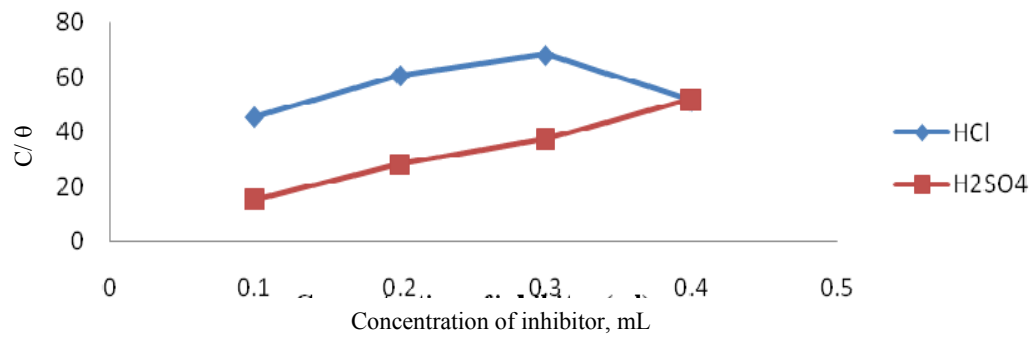

Figure 8. Langumuir adsorption isotherms after the addition of inhibitor used for carbon steel in one molar solution of $\mathrm{HCl}$ and $\mathrm{H}_{2} \mathrm{SO}_{4}$

\section{Potentiodynamic polarization tests}

The values of electrochemical parameters, i.e., corrosion current density $\mathrm{i}_{\text {corr }}$ ), corrosion potential $\left(\mathrm{E}_{\mathrm{corr}}\right)$, Tafel slops $\left(\beta_{\mathrm{c}}\right)$ and inhibitor efficiency $\left(\mathrm{IE}_{\mathrm{T}}, \%\right)$ obtained as function of different are measured.

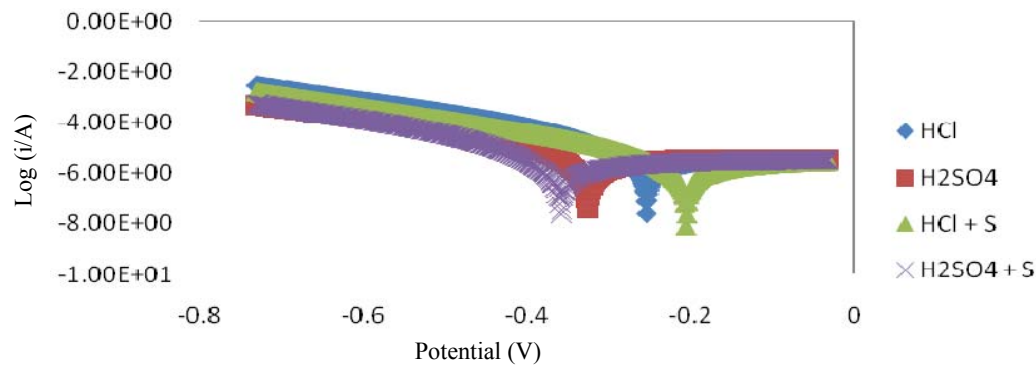

Figure 9. Potentiodynamic polarization curves for carbon steel in one molar solution of $\mathrm{H}_{2} \mathrm{SO}_{4}$ and $\mathrm{HCl}$ solution and after addition of inhibitor $\mathrm{S}$ 


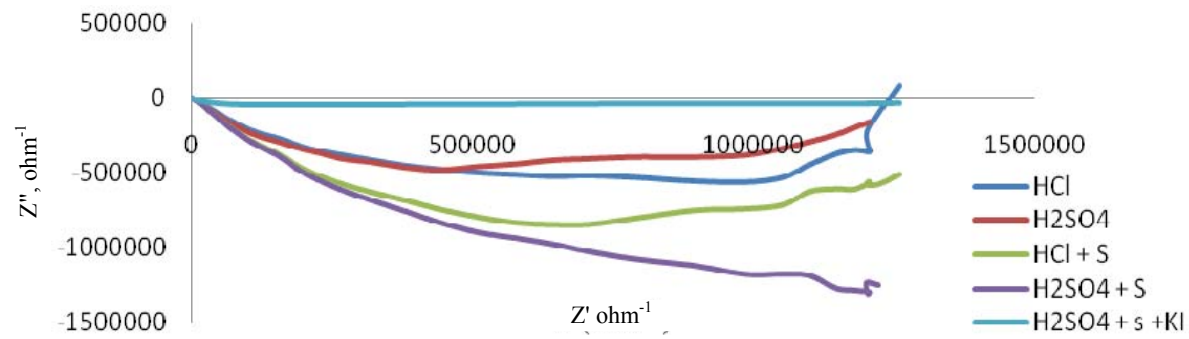

Figure 9. Nyquist diagram for mild steel in one molar solution of $\mathrm{H}_{2} \mathrm{SO}_{4}$ and $1 \mathrm{M} \mathrm{HCl}$ in presence and absence of inhibitor

\section{Conclusion}

From the principal result of the present work we can conclude that:

- $\quad$ The pyrazole compound was synthesised under convectional method and characterized by FTIR, ${ }^{1} \mathrm{H}$ NMR, ${ }^{13} \mathrm{C}$ NMR.

- The synthesized 1-acetyl-4,5-dihydro-5-phenyl-3-(thiophen-2yl) pyrazoles has showed the tatuomeric form (ionic liquid) property.

- The melting point of the 1-acetyl-4, 5-dihydro-5-phenyl-3-(thiophen-2yl) pyrazole = $94{ }^{\circ} \mathrm{C}$

- The ability of the synthesized compound on to the corrosion inhibition was checked by one molar solution of $\mathrm{HCl}$ and $\mathrm{H}_{2} \mathrm{SO}_{4}$ medium on mild steel by both weight loss and polarisation studies.

- Polarization study showed that the compound under investigation was mixed type inhibitor.

- The inhibition efficiency of the inhibitor increased with increases of the concentration, decreased with increasing temperature and their addition led to a increase of the activation corrosion energy.

- The weight loss, polarization curves and electrochemical impedance spectroscopy were in good agreement.

- Adsorption of the inhibitor on the carbon steel surface from molar solution of $\mathrm{H}_{2} \mathrm{SO}_{4}$ and $\mathrm{HCl}$ followed the Langmuir isotherm.

\section{References}

1. Natalya V, Likhanova, Octivio Olivares-Xometl, Diego Guzman Lucero, Int $J$ Electrochem Sci., 2011, 6, 4514-4536.

2. Sastri V S, Corrosion Inhibitors Principles and Applications, John Wiley \& Sons, New York, 1998.

3. Abd El-Rehim S S A, Ibrahim M A M and Khaled K F, J Appl Electrochem., 1999, 29(5), 593-599.

4. Ferreira E S, Giacomelli C, Giacomelli F C and Spinelli A, Mater Chem Phys., 2004, 83(1), 129-134; DOI:10.1016/j.matchemphys.2003.09.020

5. Fontana M G, Corrosion Engineering, Third Ed., McGraw-Hill, Singapore, 1986.

6. Abboud Y, Abourriche A, Saffaj T, Berrada M, Charrouf M, Bennamara A and Hannache H, Desalination, 2009, 237(1-3), 175-189;

DOI:10.1016/j.desal.2007.12.031

7. Sinko J, Prog Org Coat., 2001, 42(3-4), 267-282; DOI:10.1016/S03009440(01)00202-8 
8. Manahan S E, Environmental Chemistry, Sixth Ed., Lewis, Boca Raton, 1994.

9. Krim O, Bouachrine M, Hammouti B, Elidrissi A and Hamidi M, Port Electrochim Acta, 2008, 26, 283-289.

10. Quraishi M A and Shukla S K, Mater Chem Phys., 2009, 113(2-3), 685-689; DOI:10.1016/j.matchemphys.2008.08.028

11. Bentiss F, Traisnel M, Gengembre L and Lagrenee M, Appl Surf Sci., 2000, 161(1-2), 194-202; DOI:10.1016/S0169-4332(00)00287-7

12. Cruz J, Martez R, Genesca J and Garcia-Ochoa E, J Electroanal Chem., 2004, 566(1), 111-121; DOI:10.1016/j.jelechem.2003.11.018

13. Bouklah M, Ouassini A, Hammouti B and El Idrissi A, Appl Surf Sci., 2005, 250(14), 50-56; DOI:10.1016/j.apsusc.2004.12.021

14. Popova A, Christov M, Raicheva S and Sokolova E, Corros Sci., 2004, 46(5), 1333 1350; DOI:10.1016/j.corsci.2003.09.025

15. Ibrahim M A M, Messali M, Moussa Z, Alzahrani A Y, Alamry S N and Hammouti B, Portug Electrochim Acta, 2011, 29(6), 375-389; DOI:10.4152/pea.201106375

16. Messali M, J Mater Environ Sci., 2011, 2(2), 174-185.

17. Zarrouk A, Messali M, Zarrok H, Salghi R, Ali A A, Hammouti B, Al-Deyab S S and Bentiss F, Intern J ELectrochem Sci., 2012, 7(8), 6998-7015.

18. Zarrouk A, Messali M, Aouad M R, Assouag M, Zarrok H, Salghi R, Hammouti B and Chetouani A, J Chem Pharm Res., 2012, 4(7), 3427-3436.

19. Quraishi M A, Rafiquee M Z A, Khan S and Saxena N, J Appl Electrochem., 2007, 37(10), 1153-1162; DOI:10.1007/s10800-007-9379-0

20. Ben Hmamou D, Aouad M R, Salghi R, Zarrouk A, Assouag M, Benali O, Messali M, Zarrok H and Hammouti B, J Chem Pharm Res., 2012, 4(7), 3489-3497.

21. Ghazoui A, Bencaht N, Al-Deyab S S, Zarrouk A, Hammouti B, Ramdani M and Guenbour M, Intern J ELectrochem Sci., 2013, 8(2), 2272-2292.

22. Guendouz A, Missoum N, Chetouani A, Al-Deyab S S, Ben Cheikhe B, Boussalah N, Hammouti B, Taleb M and Aouniti A, Intern J ELectrochem Sci., 2013, 8(3), 4305-4327.

23. Ezhilarasi M R, Prabha B and Santhi T, Rasayan J Chem., 2015, 8(1) ,71-83.

24. Lubanski Fragoza-Mar, Octavio Olivares-Xometl, Marco A Domínguez-Aguilar, Eugenio A Flores, Paulina Arellanes-Lozada and Federico Jiménez-Cruz, Corros Sci., 2012, 61, 171-184; DOI:10.1016/j.corsci.2012.04.031

25. Punita Mourya, Sitashree Banerjee and Singh M M, Corros Sci., 2014, 85 , 352-363; DOI:10.1016/j.corsci.2014.04.036 